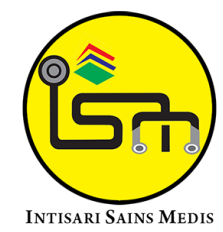

Published by Intisari Sains Medis

\section{Potential effect of secondary metabolites in Persea americana seeds as an a-amylase inhibitor on type 2 diabetes mellitus}

\author{
Anak Agung Bagus Putra Indrakusuma', Luh Putu Sudi Wahyuni', I Gede Wikania Wira Wiguna', \\ Anggi Amanda Triana Devy ${ }^{1}$, I Gede Aswin Parisya Sasmana' ${ }^{1}$, Agung Wiwiek Indrayani2 ${ }^{2 *}$
}

'Faculty of Medicine, Udayana University, Bali, Indonesia;

${ }^{2}$ Department of Pharmacology and Therapy Faculty of Medicine, Udayana University, Bali, Indonesia;

\section{*Corresponding author:}

Agung Wiwiek Indrayani;

Department of Pharmacology and Therapy Faculty of Medicine, Udayana University, Bali, Indonesia; agungwiwiek@unud.ac.id

Received: 2021-08-24

Accepted: 2021-12-02

Published: 2021-12-20

\section{ABSTRACT}

Background: Type 2 diabetes mellitus (T2DM) is a disease that has a high prevalence in the world. The development of plants with medicinal potential is an alternative to control blood sugar levels in T2DM disease, such as avocado (Persea americana). Persea americana seeds contain secondary metabolites that have anti-diabetic activity, but their bioavailability is low.

Aim: This study aims to review various secondary metabolites in Persea americana seeds that can reduce blood glucose levels in a-amylase pathway along with the type of potential encapsulation as a delivery system.

Review: Secondary metabolites contained in Persea americana seeds which have activity as anti-diabetic are tannin, quercetin, rutin, kaempferol, saponin, triterpenoid, and alkaloid. Each of them has several mechanisms in diabetes, but their role as a-amylase inhibitor on T2DM be in focus. There are various types of encapsulation that are known to be able to serve as a delivery system for these secondary metabolites. Those encapsulations are SNEDDS, chitosan-alginate nanoparticle, PLGA nanoparticle, lipid carrier, liposome, and polysaccharide-based enteric-coated nanoparticle. All of them showed good results in improving bioavailability.

Conclusion: It is known that various secondary metabolites found in Persea americana seeds influence reducing blood glucose levels notably in the a-amylase pathway. The low bioavailability of secondary metabolites can be improved by several forms of potential encapsulation. Therefore, herbal substances as adjuvant therapy in T2DM might be a viable management option.

Keywords: a-amylase, encapsulation, Persea americana seeds, type 2 diabetes mellitus.

Cite This Article: Indrakusuma, A.A.B.P., Wahyuni, L.P.S., Wiguna, I.G.W.W., Devy, A.A.T., Sasmana, I.G.A.P., Indrayani, A.W. 2021. Potential effect of secondary metabolites in Persea americana seeds as an a-amylase inhibitor on type 2 diabetes mellitus. Intisari Sains Medis 12(3): 886-896. D0I: 10.15562/ism.v12i3.1119

\section{INTRODUCTION}

Diabetes mellitus (DM) is a metabolic disease characterized by hyperglycemia caused by a failure in insulin secretion (type 1) or insulin resistance by pancreatic $\beta$-cells (type 2). ${ }^{1}$ In recent years, the number of cases and prevalence of diabetes continues to increase. Globally, WHO states that 422 million people aged over 18 years lived with diabetes in 2014 and caused 1.5 million deaths in 2012. The prevalence of DM in Indonesia in 2018 was $1.2 \%$ but is expected to increase in 2030 to reach 21.3 million sufferers, especially in type $2 \mathrm{DM}$ (T2DM). ${ }^{2}$ The high prevalence of type 2 diabetes mellitus is due to risk factors, namely risk factors that cannot be changed and which can be changed. Non-modifiable risk factors such as gender, age, birth weight, genetic factors. While modifiable risk factors such as smoking, stress, alcohol consumption, poor diet, and overweight. ${ }^{3}$

Management of diabetes mellitus aims to prevent and inhibit the progression of complications and reduce mortality and morbidity. One of the modalities used in the management of T2DM today is acarbose. These drugs are chemical inhibitors of $\alpha$-amylase and $\alpha$-glucosidase by preventing hyperglycemia by inhibiting glucose absorption. However, the use of acarbose has major side effects such as abdominal distension, flatulence with nausea and vomiting, and diarrhea. ${ }^{4}$

The development of herbal plants is an alternative for controlling blood sugar levels in DMT2. Herbal plants are believed to have relatively few side effects when used in appropriate doses compared to chemical drugs. ${ }^{5}$ One of the beneficious plants constructed as herbal medicine is the avocado seed (Persea americana). Avocado production in Indonesia continues to increase every year. This is evidenced by the total production reaching 363,157 tons in 2017 and an increase of $19.09 \%$ compared to 2016 . Therefore, the use of avocado as herbal medicine is very potential. ${ }^{6}$

Avocado plants have been widely known to have anti-inflammatory and analgesic properties. Avocado seeds have various uses such as diarrhea medicine, toothache, as well as skin and beauty treatments. Previous research stated 
that avocado seed extract at a dose of $1200 \mathrm{mg} / \mathrm{kgBW}$ could reduce blood glucose levels in white male rats with an average decrease of $134.8 \mathrm{mg} / \mathrm{dL} .^{7}$ Avocado seeds contain secondary metabolic compounds with anti-diabetic activity, namely flavonoids, alkaloids, saponins, and tannins. ${ }^{5}$ Secondary metabolites are not directly involved compounds in the growth, development, or reproduction of living things. Secondary metabolites are produced by plants in certain quantities under certain conditions. ${ }^{8}$

Flavonoid compounds play a role in protecting the intestinal surface and can inhibit glucose absorption and reduce the rate of increase in blood sugar levels. Alkaloids have been shown to have the ability to regenerate damaged pancreatic cells. Increased insulin secretion is caused by the sympathetic nervous stimulation effect of alkaloids. ${ }^{9}$ Saponins can stimulate insulin secretion from pancreatic cells, increasing the amount of blood glucose that enters the cells, resulting in a decrease in blood sugar levels. ${ }^{5}$ Tannins in avocado seeds play a role in preventing hyperglycemia by inhibiting the activity of the $a$-amylase enzyme. ${ }^{10}$ These enzymes degrade complex dietary oligosaccharides and disaccharides and are then converted to monosaccharides by a-glucosidase.

However, these compounds have a weakness, namely their low bioavailability when entering the digestive process, thus encapsulation is necessary. Various methods of encapsulation have been shown to transport secondary metabolites effectively. Nanoemulsions, such as SNEDDS, are regarded as one of the most acceptable kinds of encapsulation due to their advantages, including small droplet size and kinetically stable colloidal systems. In contrast to traditional emulsions, they offer better functional characteristics. For the encapsulation and efficient distribution of bioactive lipophilic substances, the content and structure of nanoemulsions can be regulated. ${ }^{11}$ Other potential encapsulation forms are chitosan-alginate nanoparticles, PLGA nanoparticles, lipid carriers, liposomes, and polysaccharide-based enteric-coated nanoparticles. ${ }^{12-17}$ This study aims to analyze various secondary metabolites in Persea americana seeds that can reduce blood glucose levels in the a-amylase pathway and the type of potential encapsulation as a delivery system.

\section{METHOD}

The author used the literature review method in this study. The data were obtained from relevant literature sources from search engines such as Google Scholar, Pubmed, and ScienceDirect. The literature was further filtered according to inclusion and exclusion criteria. Inclusion criteria include journals containing keywords ( $a$-amylase, encapsulation, Persea americana seeds, type 2 diabetes mellitus), both journal review articles, and a maximum journal period of the last ten years. The exclusion criteria are journals that do not discuss information on keywords, journal protocol only articles, and have a maximum journal period of the previous ten years unless there is no recent research relevant to the reference of this study. Of the many journals reviewed, 97 journals are suitable to be used as references in writing this review article.

\section{REVIEW}

\section{Pathogenesis of Type 2 Diabetes Mellitus}

T2DM is a chronic disease caused by insulin resistance. T2DM is a pathological condition caused by various factors, such as lifestyle, genetics, autoimmune, and others. Diabetes mellitus with impaired insulin function in the body, either due to failure of pancreatic cells to secrete insulin (e.c autoimmune, pancreatic necrosis, etc.) or insulin resistance in peripheral tissues. Insulin resistance itself is clinical with several conditions, such as the insulin concentration required to maintain glucose levels within normal limits or the presence of inadequate insulin signaling strength from downstream insulin receptors to the end-acting insulin substrate. ${ }^{18}$

The insulin receptor (IR) is a heterotetramer molecule. This receptor consisting two a-subunits and two $\beta$-subunits which are bound together by disulfide bonds. Insulin will then bind to the subunit of the IR and activate the tyrosine kinase, which invites autophosphorylation of the subunit to amplify the tyrosine kinase activity. Furthermore, insulin's metabolism and antiapoptotic effects are mediated by signaling pathways involving the phosphorylation of insulin receptor substrate-1 (IRS-1) and protein kinase. ${ }^{19,20}$ Insulin resistance will cause glucose abnormalities caused by disruption of the type 4 glucose transporter translocation (GLUT-4), which facilitates glucose diffusion circulation and increases glucose transport into cells. Translocation of GLUT-4 is the result of the occurrence between insulin and IR in cellular which then triggers a phosphorylation reaction that can regulate insulin activity. ${ }^{21}$

Autophosphorylation that occurs, especially in the amino acid tyrosine, will strengthen the work of the tyrosine kinase enzyme, which further phosphorylates intracellular proteins such as IRS-1. This process then generates secondary signals related to insulin receptors, one of which is the $a$-amylase enzyme. The activity of

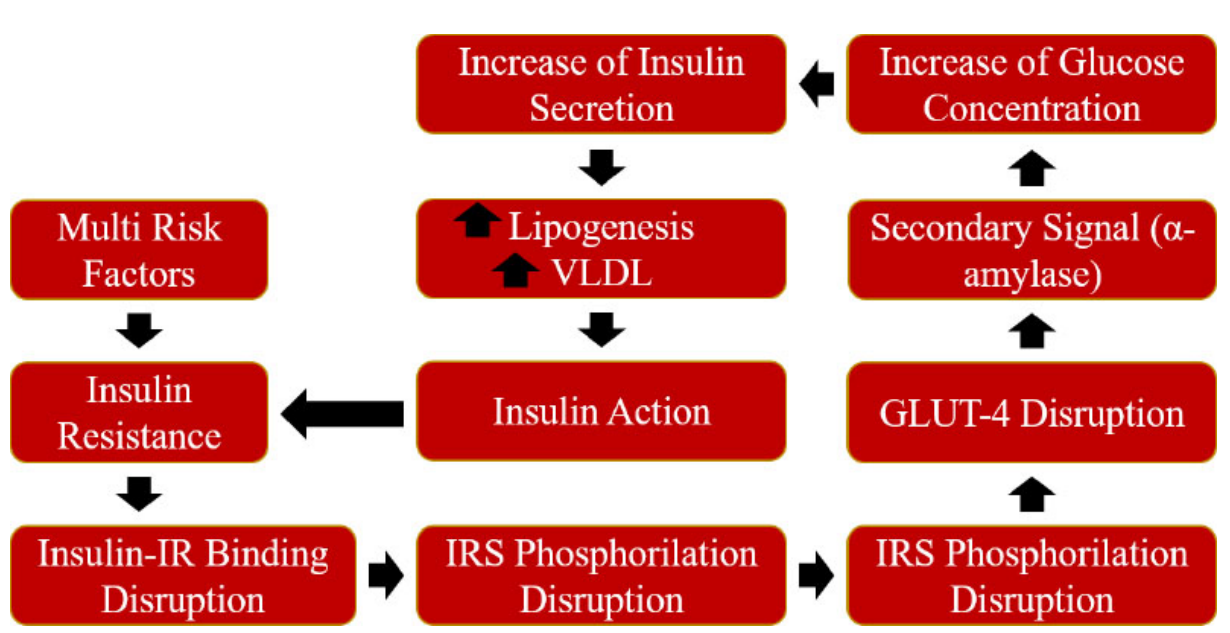

Figure 1. Pathogenesis of T2DM. ${ }^{23}$ 
the $\alpha$-amylase enzyme that plays a role in glucose absorption will impact the signal. An $a$-amylase acts as a catalyst in the alpha-1,4 glycosidic hydrolysis reaction of starch, amylopectin, amylose, glycogen, and maltodextrin and is responsible for starch digestion. Levels of this enzyme will also increase the increase in glucose in the blood to trigger hyperglycemia. The rise in blood glucose levels then causes an increase in the need for insulin in peripheral tissues to enter the cells so that it becomes an interconnected process and the conditions of diabetes mellitus are interrelated. ${ }^{22}$ The level of insulin secreted by the pancreas also has an impact on adipose tissue. The increase of insulin secretion will increase lipogenesis in the liver and increase the secretion of very-low-density lipoprotein (VLDL). Furthermore, those effects can trigger other metabolic diseases including hypertriglyceridemia and obesity. This condition then causes a decrease in insulin action in peripheral tissues so that this cycle will continue to repeat in patients with T2DM (Figure 1). ${ }^{23}$

\section{Secondary Metabolites in Persea americana Seeds}

There are various secondary metabolites contained in Persea americana seeds based on literature studies. These secondary metabolites are known to have antidiabetic effects through multiple studies (Table 1). Each of them can reduce blood glucose.

\section{Tannin}

Tannin is a water-soluble phenolic derivative that can be found naturally in several types of plants. From the research that has been done, tannin has some biological activities, such as an anti-diabetic, anti-bacterial, anti-viral, antioxidant, anti-cancer agent, and has many other benefits. The chemical structure of tannins is highly dependent on the type of plant that produces them. In general, tannins can be classified into two main groups, condensed tannins (unhydrolyzed tannins) called procyanidins and hydrolyzed tannins. Hydrolyzed tannins are generally available in small amounts in plants. This molecule has a polyol group (D-glucose) as its center, partially or completely esterified with a phenolic group such as ellagic acid or gallotanin acid. Condensed tannins are a group of polyphenolic bioflavonoids with condensable carbon molecules. The chemical structure of tannins greatly affects their biological activity. ${ }^{39,40}$ Tannins can be found in several plants, such as berries, apples, peaches, pomegranates, nuts, and avocados. Avocado seeds contain $0.24 \mathrm{mg} / 100 \mathrm{~g}$ of tannins, while the flesh contains only $0.12 \mathrm{mg} / 100 \mathrm{~g} .{ }^{41}$

Tannins have several mechanisms in controlling blood glucose levels. As an antioxidant, tannin has a protective function to ward off free radicals and activate antioxidant enzymes. Concerning endocrine organs, the role of tannin as an antioxidant can support the growth, regeneration, and protection of pancreatic

Table 1. Secondary metabolites in Persea americana seeds.

\begin{tabular}{|c|c|c|}
\hline $\begin{array}{l}\text { Secondary } \\
\text { Metabolites }\end{array}$ & Effects in Diseases & References \\
\hline Tannin & $\begin{array}{l}\text { - Protects and supports pancreatic } \beta \text { cells regeneration } \\
\text { - } \quad \text { Stimulates the translocation of GLUT- } 4\end{array}$ & 24,25 \\
\hline Quercetin & $\begin{array}{l}\text { - Protection to pancreas against oxidative stress } \\
\text { - Promoting regeneration of pancreas } \\
\text { - Inducing secretion of insulin } \\
\text { - Stimulate the translocation of GLUT-4 } \\
\text { - Inhibit GLUT-2 activation }\end{array}$ & $26-28$ \\
\hline Rutin & $\begin{array}{l}\text { - Inhibits glucose absorption in the small intestine } \\
\text { - Stimulates activation and translocation of GLUT-4 } \\
\text { - Increase expression of PPAR } \gamma \\
\text { - Inhibits the gluconeogenic enzymes (PPECK and G6Pase) } \\
\text { - } \text { Protects pancreatic } \beta \text { cells } \\
\text { - Increase insulin secretion and sensitivity }\end{array}$ & 29-31 \\
\hline Kaempferol & $\begin{array}{l}\text { - Protecting pancreatic cells from lipid peroxide } \\
\text { - Increases glucose oxidation in muscles } \\
\text { - Inhibits gluconeogenesis }\end{array}$ & 32 \\
\hline Saponin & $\begin{array}{l}\text { - Protects pancreatic cells from oxidative stress } \\
\text { - Stimulates insulin secretion, sensitivity, and activation } \\
\text { - Increases glucose utilization in peripheral organs } \\
\text { - Increases glucose uptake in 3T3-L1 adipocytes via increased (PPAR)- } \gamma \\
\text { - Inhulate the GLUT4 translocation } \\
\text { Inhits gluconeogenesis }\end{array}$ & 33,34 \\
\hline Triterpenoid & $\begin{array}{l}\text { - Stimulates PPAR- } \gamma \text { activation } \\
\text { - Increasing the expression and translocation of GLUT-4 } \\
\text { - Protects pancreatic } \beta \text { cells from oxidative stress } \\
\text { - Inhibits glucose absorption by inhibition of GLUT2 and SGLT1 }\end{array}$ & 35,36 \\
\hline Alkaloid & $\begin{array}{l}\text { - Stimulate the GLUT4 translocation } \\
\text { - Increase PPAR- } \gamma \text { gene expression } \\
\text { - } \quad \text { Protect pancreatic cells from oxidative stress }\end{array}$ & 37,38 \\
\hline
\end{tabular}


cells. The antioxidant test showed the ability of tannic acid to inhibit lipid peroxide up to $97.7 \% .^{24}$ In addition, tannins contribute to increased blood glucose uptake to peripheral organs through mediators of the insulin signaling pathway. Tannins can also increase the expression and translocation of glucose transporter 4 (GLUT-4). GLUT-4 translocation is initiated by the binding of the IRS protein which further activates a signaling pathway that involves the activation of mitogen-activated protein kinase (MAPK). GLUT-4 is a glucosecarrying molecule in cell membranes that is important for glucose transport in muscle cells and adipose tissue. ${ }^{40}$ In previous studies showed that procyanidins (condensed tannins) can significantly increase GLUT-4 translocation mediated by insulin and MAPK signaling pathways in mice muscle $(\mathrm{p}<0.05){ }^{25}$

\section{Flavonoids}

Flavonoids are polyphenols that are commonly found in fruits, vegetables, and nuts. This substance consists of 15 carbon skeletons and two aromatic rings (A and B) linked by 3 carbon chains, usually oxygenated heterocyclic $\mathrm{C}$ rings. Their chemical structure divides flavonoids into six main subclasses: flavonones, flavonols, flavan-3-ols, anthocyanosides, and isoflavones. Flavonoids are the largest phytochemicals in avocado seeds with a composition of up to $20.33 \mathrm{mg} / 100 \mathrm{~g}$. This compound is the dominant compound that functions as an antioxidant to protect body cells from oxidative stress. In addition, flavonoids also have various functions in the body, such as anti-cancer, anti-bacterial, antiviral, and so on. ${ }^{42,43}$

\section{Quercetin}

One of the most abundant flavonoids in avocado seeds is quercetin. This substance belongs to the flavonols subclass that cannot be produced by the human body and is a substance that has various functions as a pharmacological therapy modality for metabolic and inflammatory disorders. Quercetin can be used as anti-diabetic, cardiovascular disease prevention, anti-cancer, anti-bacterial, anti-viral, anti-inflammatory, antioxidant, and many other benefits. ${ }^{44}$ Quercetin can be found in certain parts of certain plants, such as fruit. grapes, oranges, cherries, including avocado seeds. ${ }^{45}$

Quercetin can act as an antihyperglycemic agent through several mechanisms, such as maintaining glucose homeostasis, maximizing glucose utilization in peripheral organs or tissues, increasing insulin sensitivity and secretion, and preventing glucose absorption in the digestive tract. $^{27}$ Quercetin can stimulate the translocation and expression of GLUT-4 via the adenosine monophosphate-activated protein kinase (AMPK) signaling pathway in mitochondria and increases glucose uptake in muscle cells. Hyperglycemia conditions cause an increase in the number of free radicals (ROS), which can cause tissue and insulin receptor (IRS1) damage, leading to insulin resistance. As an antioxidant, quercetin was found to ward off free radicals, especially lipid peroxides, reduce DNA damage in hyperglycemic conditions, and protect pancreatic cells from oxidative stress. This is supported by previous researches which showed the ability of quercetin to increase GLUT-4 expression and improved DNA protection in hyperglycemic rats. ${ }^{26}$

One type of protein that is still included in the glucose transporter family is GLUT2 . This protein plays a role in the absorption of glucose in the small intestine. Increased the expression of GLUT 2 will increase glucose absorption that affects the level of glucose in the circulation. Quercetin can inhibit the activation of GLUT-2, thereby reducing glucose absorption in the gastrointestinal tract. In addition, quercetin was also able to increase insulin secretion through the ERK1/2 signaling pathway and protect pancreatic $\beta$-cell function in vitro study using INS- 1 cell culture significantly $(\mathrm{p}<0.05)$. It also contributes to increased insulin sensitivity and decreased blood glucose levels. ${ }^{28}$

\section{Rutin}

Rutin is a type of polyphenol that can be found in avocado seeds. Rutin has various functions, such as controlling blood glucose level and lipid profile, being an antioxidant, and maintaining healthy kidneys, nerves, and the liver. This compound has several pathways in regulating blood glucose. Rutin plays a role in inhibiting glucose absorption in the digestive tract by inhibiting glucosesplitting enzymes, such as maltase, isomaltase, and glucoamylase which can prevent high postprandial blood glucose levels. ${ }^{46}$ Rutin also can increase the activation and translocation of GLUT-4 via PI3K and MAPK pathway to increase glucose uptake to peripheral tissues. ${ }^{29}$

Rutin extract administration can also increase glucose uptake in adipose tissue. Adipose tissue is formed from calories circulating in the circulation through the process of lipogenesis and then differentiates into mature tissue through the process of adipogenesis. Rutin was able to significantly increase the expression of the PPAR $\gamma$ gene that contributes to the adipogenesis process $(\mathrm{p}<0.001)$ and increase glucose uptake in muscle cells significantly $(\mathrm{p}<0.05) .{ }^{30}$ Rutin was found can inhibit gluconeogenesis, the process of converting non-glucose materials into glucose. This is one of the main causes of hyperglycemia. Inhibition is done by reducing the expression of gluconeogenic enzymes such as phosphoenolpyruvate carboxykinase (PEPCK) and glucose6-phosphatase (G6Pase). Rutin can stimulate insulin secretion and can prevent pancreatic $\beta$-cell degeneration. ${ }^{46}$ Rutin was also found to significantly increase insulin sensitivity in Wistar rats. ${ }^{31}$

\section{Kaempferol}

Kaempferol is a flavonoid from the flavonol subclass that can be found in vegetables and fruits. In avocado seeds, the content of kaemferol reaches 10.74 $\mathrm{mg} / 100 \mathrm{~g} .{ }^{42}$ Kaemferol has various benefits, especially as antimicrobial, antioxidant, anti-inflammatory, anticancer, including maintaining blood glucose homeostasis. This substance acts as an antioxidant that can inhibit free radicals, protect pancreatic cells and increase glucose uptake. In addition, kaempferol was also able to increase glucose oxidation in the muscles of diabetic rats. The process of gluconeogenesis can also be influenced by kaempferol because kaempferol can inhibit hepatic pyruvate carboxylase activity so that less glucose will accumulate in the circulation. ${ }^{32}$ 


\section{Saponin}

Saponins are amphipathic glycosides that chemically consist of aglycone and glycone that several types of plants can synthesize. Avocado seeds contain saponins with concentrations reaching $0.52 \mathrm{mg} / 100 \mathrm{~g}$. Saponins have a significant role in various biological activities that are promising as therapeutic modalities. These compounds are an anti-tumor, antimicrobial, anti-inflammatory, hepatoprotective agent, and anti-hyperglycemic. Saponins are one type of antioxidant that can counteract free radicals. Oxidative stress is an essential component that contributes to the development of diabetes mellitus. Oxidative stress can also react with polyunsaturated fatty acids which can cause lipid peroxidation and stimulate pancreatic cells death program. ${ }^{42,47}$

Saponins also stimulate insulin secretion and activation, regenerate pancreatic cells, and increase glucose utilization in peripheral organs. A previous study showed saponin's effect in increasing insulin-stimulated glucose uptake in 3T3-L1 adipocytes through a signaling pathway involving peroxisome proliferator-activated receptors (PPAR)- $\gamma$. In addition, this study demonstrated the role of saponins in increasing insulin sensitivity and GLUT-4 translocation to accelerate glucose uptake to peripheral tissues. ${ }^{33}$ Saponins are also involved in inhibiting gluconeogenesis by inhibiting the enzymes fructose-1,6 bisphosphates, and glucose-6-phosphate and also can increase glucose oxidation. ${ }^{34}$

\section{Triterpenoid}

Triterpenoids are secondary metabolites produced by several types of plants, one of which is avocado. These compounds play a role in several biological activities such as antioxidants, anti-inflammatory, anticancer, anti-diabetic, etc. As an antidiabetic agent, triterpenoids can activate PPAR- $\gamma$ through the AMPK signaling pathway to increase glucose uptake and metabolism in peripheral tissues. Triterpenoids were also found to be able to increase the expression and translocation of GLUT-4, a protein that plays a role in glucose transport into peripheral tissues. Like the antioxidants described in the previous compounds, triterpenoids also protect pancreatic $\beta$ cells from free radicals and promote the growth and regeneration of pancreatic $\beta$ cells. ${ }^{35}$

A previous study suggests the role of triterpenes in inhibiting the absorption of glucose from the digestive tract. One protein transport that plays a role in glucose transport in the small intestine is the sodium-dependent glucose cotransporter (SGLT1) located in the apical part of the small intestine. In hyperglycemic conditions, an increase in GLUT-2 and SGLT1 expression is often found, affecting postprandial glucose levels. Triterpenoids were found to reduce the expression of GLUT-2 and SGLT1 in vitro studies to reduce blood glucose levels. ${ }^{36}$

\section{Alkaloid}

Alkaloids are secondary metabolic products that can be found in 14$20 \%$ of plants. Avocado seeds contain alkaloids as much as $5.4 \mathrm{mg} / 100 \mathrm{~g}$. These compounds have various functions, such as antimicrobial, anti-inflammatory, antioxidant, and anti-diabetic. As an antidiabetic agent, alkaloids can stimulate GLUT-4 translocation and increase PPAR- $\gamma$ gene expression, contributing to glucose uptake to peripheral tissues. ${ }^{37}$ In its role as antioxidants, alkaloids can protect pancreatic $\beta$ cells from oxidative stress. $^{38}$

\section{The Role of Secondary Metabolites as An a-Amylase Inhibitor}

Both $\alpha$-amylase and $\alpha$-glucosidase are often targeted to develop medications for hyperlipidemia, obesity, and diabetes mellitus. ${ }^{48} \alpha$-amylase plays a crucial role in carbohydrate food digestion by catalyzing the hydrolysis of $\alpha$-(1,4)-D-glycosidic bonds or other glucose polymers from starch. ${ }^{49}$ An a-glucosidase is an enzyme that catalyzes the final phase of digestion of the matching monosaccharides and disaccharides. ${ }^{48}$ Inhibition of both carbohydrate hydrolyzing enzymes could reduce the increase of blood glucose level

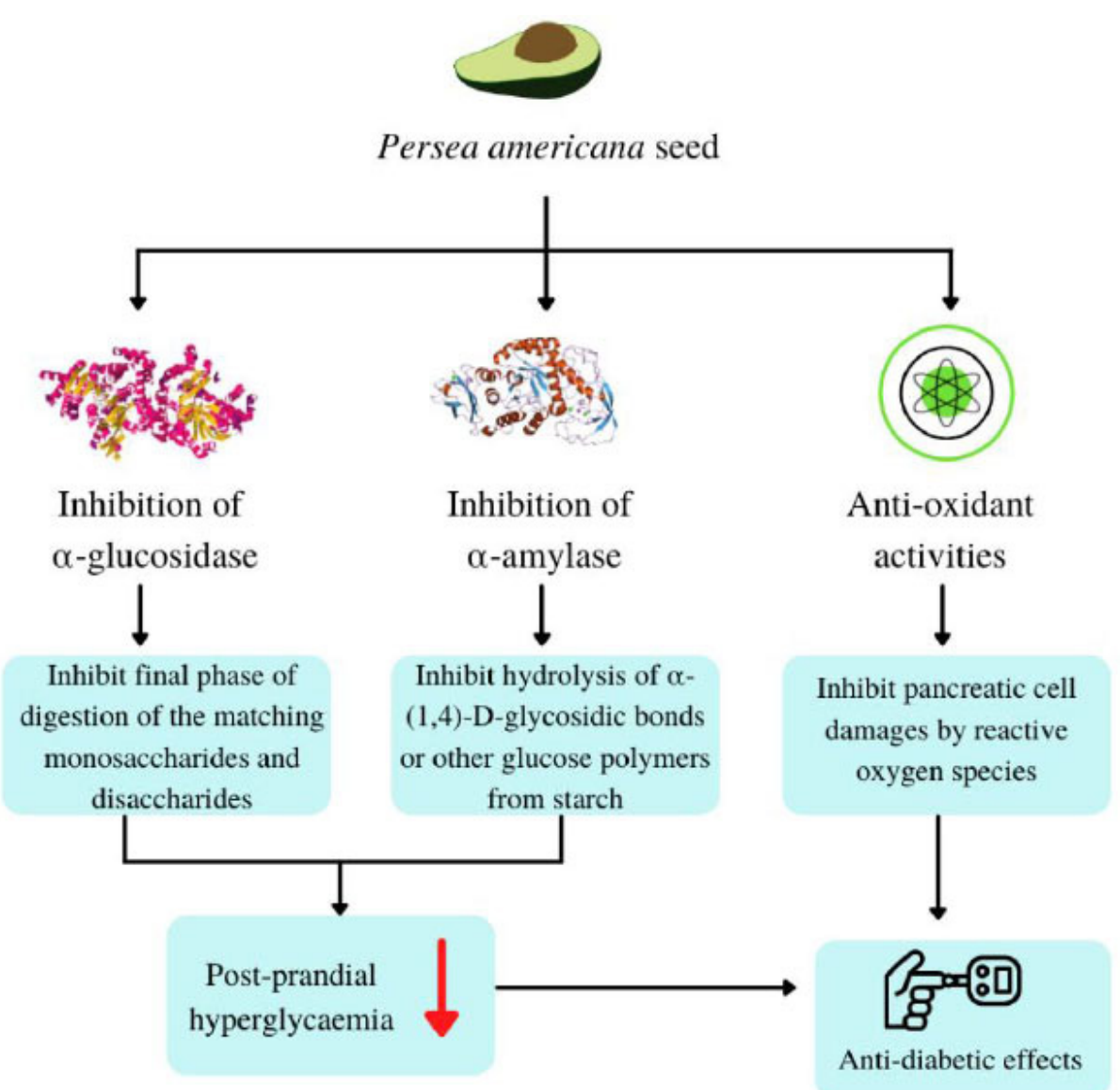

Figure 2. The hypoglycaemic activities of Persea americana seed. ${ }^{48,53}$ 


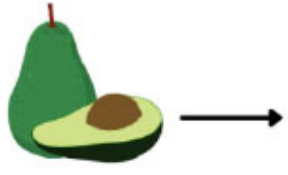

Extract of Persea americana seed

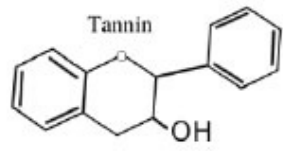

Procyanidin in condensed tannin as $\alpha$-amylase inhibitor
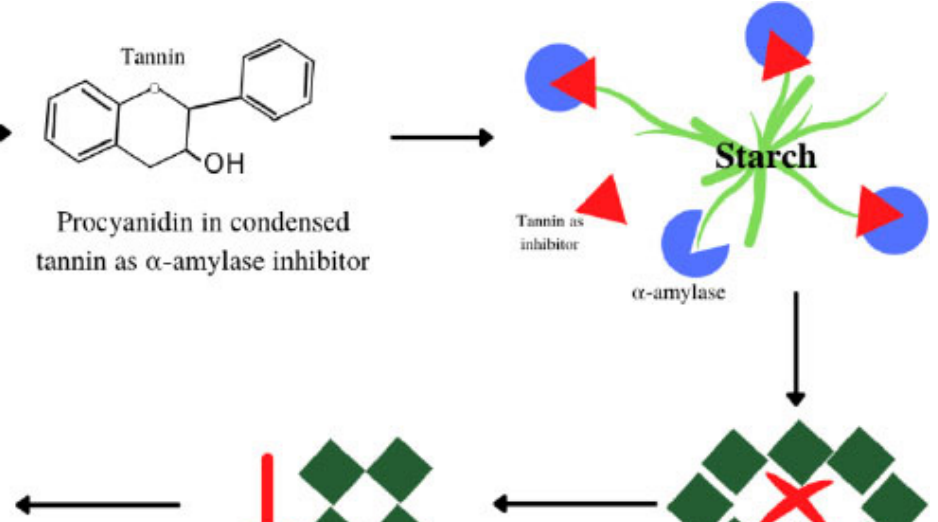

I

Hyperglycemia avoided

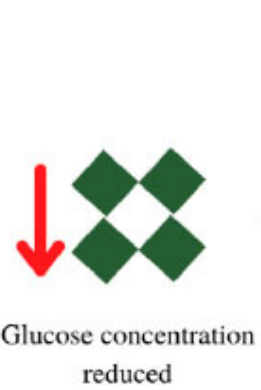
reduced diabetic activity each at the 2 and 4 hours of administration. ${ }^{60}$

Inhibitions of $\alpha$-amylase also can be done by saponin, with the competitive mode of inhibition. This means that saponin competed with the substrate at the active site of the enzyme. As an $\alpha$-amylase inhibitor, saponin can delay the digestion of carbohydrates which decreases glucose absorption in the intestine. Therefore, this substance can inhibit the postprandial plasma glucose to rise. The mode of inhibition of saponin in $D$. basuticus extract shows strong inhibition for a-glucosidase but mild inhibition for $a$-amylase. ${ }^{61}$ Meanwhile, there are still not many studies that examine the inhibition of $\alpha$-amylase specifically by saponin in Persea americana seeds.

Terpenoids have various structures, are made of isoprene units, and can be found in fruits, vegetables, and mushrooms. Each isoprene unit consists of five carbon atoms with double bonds. Studies have shown that monoterpenes and sesquiterpenes in citrus may play a role in $\alpha$-amylase inhibition. ${ }^{54}$ Terpenoids with six isoprene units called triterpenes. Oleanolic and ursolic type triterpenes in Phyllanthus amarus can inhibit porcine pancreatic $a$-amylase. The $\mathrm{IC}_{50}$ value of the mixture of these compounds was $4.41 \mu \mathrm{M} .{ }^{62}$ However, there are still not many studies that discuss terpenoids in Persea americana seeds as an $a$-amylase inhibitor.

Alkaloids are secondary metabolites that can be found in many species of plants. Some studies suggest the alkaloid effect as an $\alpha$-amylase inhibitor. Antidiabetic and hypolipidemic effects of carbazole alkaloid from $M$. koenigii leaves have been observed in streptozotocin (STZ) induced hyperglycaemic rats. This compound shows a weak inhibitory mode in a-glucosidase and a strong inhibitory against $\alpha$-amylase than acarbose drug. Alkaloids extract from $M$. alba leaf extract also shows significant inhibition of a-amylase. ${ }^{37}$

All of the secondary metabolites above as $\alpha$-amylase inhibitors have similar pathways in the hypoglycaemic activities. These inhibitors, also called starch blockers, can impede amylase activity. They will inhibit the formation of glucose by delaying the breakdown of carbohydrates 
Table 2. Potential encapsulation methods.

\begin{tabular}{|c|c|c|c|}
\hline Potential Encapsulation & Size $(\mathrm{nm})$ & Secondary Metabolites & References \\
\hline SNEDDS & avg 15.06 & Tannin, saponins & 12 \\
\hline Chitosan-alginate NP & $\min 91.58$ & Quercetin & 13 \\
\hline PLGA NP & $179.9 \pm 11.2 \mathrm{~nm}$ & Quercetin & 14 \\
\hline Lipid carrier & avg $1704 \pm 1015.95$ & Rutin & 15 \\
\hline Liposome & 2.12 and 0.84 & Quercetin and kaempferol & 16 \\
\hline Polysaccharide-based enteric-coated NP & - & $\begin{array}{l}\text { Saponins, tannins, alkaloids, } \\
\text { terpenoids }\end{array}$ & 17 \\
\hline
\end{tabular}

*SNEDDS = self nano-emulsifying drug delivery system; PLGA = poly lactic-co-glycolic acid; avg = average; min = minimum; NP = nanoparticle

in the small intestine. Thus, retardation of starch hydrolysis is important to avoid postprandial hyperglycemia. ${ }^{63}$ Acarbose and some drugs for $a$-amylase inhibition are unfortunately pricey and have several side effects. $^{51}$ Therefore, $\alpha$-amylase inhibitor by these secondary metabolites, which can be obtained naturally in plants and fruits, can be another effective solution as an $\alpha$-amylase inhibitor rather than a drug-based inhibitor.

\section{Potential Encapsulation Methods}

Secondary metabolites have a limited bioavailability, as previously stated. To enhance its bioavailability in the body, encapsulation is required. These secondary metabolites can be encapsulated in a variety of ways (Table 2 ).

\section{Self Nano-Emulsifying Drug Delivery System (SNEDDS)}

Self nano-emulsifying drug delivery system (SNEDDS) is an anhydrous isotropic combination of oil, surfactant, and co-surfactant which can produce nanoemulsion spontaneously when in contact with gastric fluid. SNEDDS has the potential to increase the poor bioavailability of water-soluble drugs. The formulation of SNEDDS preparations will increase the dissolution of the active substance by facilitating the formation of the solubilized phase and increasing the transport to increase the absorption and bioavailability of the active substance from the gastrointestinal tract. ${ }^{64}$

Constituent components play an important role and influence the characteristics of SNEDDS. Oil, as the main carrier of the active substance in the SNEDDS formulation, plays a role in determining the emulsion formed and the capacity of the active substance that can be carried. Surfactants play a role in reducing the droplet size of the emulsion and keeping the active substance at the absorption site for a long time so that there is no precipitation in the gastrointestinal tract. Tween 80 is a non-ionic surfactant with a Hydrophilic-Lipophilic Balance (HLB) value of 15 , which is stable for $\mathrm{o} / \mathrm{w}$ emulsions and safe for the body. Cosurfactants assist surfactants in lowering the surface tension of water and oil, increasing the dissolution of the active substance, and improving the dispersibility and absorption of the active substance. ${ }^{65}$

\section{Chitosan-alginate nanoparticle}

The most significant chitin derivative is chitosan, which is made by removing the acetate moiety from chitin. It comes from crustacean shells, such as those from prawns or crabs, as well as fungus cell walls. It's a cationic, highly basic, mucoadhesive biocompatible polymer that's been authorized by the US Food and Drug Administration for tissue engineering and drug delivery. Chitosanbased NP is particularly well suited to the mucosal route because of their low toxicity, mucoadhesion, and adjustable physical characteristics. ${ }^{66}$

Alginate is a brown algae-derived natural anionic polymer with a chemical structure of $\alpha$-L-guluronic acid and $\beta$-D-mannuronic acid. It may produce nanoparticles via ionotropic gelation with divalent cations or cationic polymers, but not stable at room temperature and encapsulated active chemicals leak easily.67-69 Therefore, encapsulating the alginate nanoparticles with chitosan were able to overcome these restrictions..$^{7,71}$

In a recent study, the toxicity of alginate/ chitosan/lovastatin (ACL) nanoparticles was sufficiently low in mice. The drug's
LD50 was greater than $5000 \mathrm{mg} / \mathrm{kg}$, and there were no abnormal symptoms, death, or toxicity to the function or structure of the vital organs in the subchronic toxicity test with doses of $100 \mathrm{mg} / \mathrm{kg}$ and $300 \mathrm{mg} /$ kg ACL nanoparticles. ${ }^{69}$ Meanwhile, the other study found that the particles with substantial $\mathrm{pH}$ sensitivity had a minimum particle size of $91.58 \mathrm{~nm}$ and 95 percent quercetin chitosan-alginate encapsulation efficiency. In diabetic rats, peroral administration of these quercetin nanoparticles resulted in a significant hypoglycaemic impact and efficient glucose homeostasis when compared to free oral quercetin. ${ }^{13}$

\section{Poly Lactic-co-Glycolic Acid (PLGA) nanoparticle}

The advantages of PLGA such as biocompatibility, biodegradability, and toxicologically acceptable breakdown products have been highly helpful for drug administration. ${ }^{72}$ The FDA has authorized PLGA for use in nanomedicine formulations in humans. ${ }^{73,74}$ PLGA is also known because of its adaption in hydrophilic or hydrophobic small molecules or macromolecules, drug degradation protection, sustained release, better interaction with biological materials, and able to target specific organs or cells. ${ }^{73}$

The final characteristics of NP, including form, size, size distribution, and stability, are influenced by their manufacturing processes. For the production of PLGA NP, various methods have been utilized, including emulsification, nanoprecipitation, dialysis, and spray drying, whether in single or double processes. ${ }^{75,76}$ While D-lactate is not further processed before being expelled, L-lactate is transformed to $\mathrm{CO} 2$ and pyruvate, which enters the Krebs 
cycle. Glycolate, on the other hand, can be eliminated directly through the kidneys or oxidized to glyoxylate, which can then be converted to glycine, serine, and pyruvate. ${ }^{73,77,78}$

In a recent study, after formulation creation, antioxidant tests revealed that quercetin in PLGA NP was able to preserve antioxidant properties similar to the free drug at equivalent concentrations. In diabetic rats, the same amount of this encapsulation given every fifth day was enough to provide an impact comparable to a daily dose of oral quercetin suspension. The same effect was shown in pancreatic and kidney catalase and superoxide dismutase levels. This benefit will result in a reduction in medication dosage, frequency, and patient complaints. ${ }^{14}$

\section{Lipid carrier}

The inclusion of liquid oil in the nanostructured lipid carriers (NLC) structure results in defective crystals with bigger empty spaces, resulting in high encapsulation effectiveness. This less orderly structure also reduces bioactive component ejection during storage. ${ }^{79}$ This encapsulation has many advantages such as better physical stability with controlled particle size, cheaper than other delivery options, lipophilic and hydrophilic encapsulation, biodegradable, high content of delivered compounds, and improving its solubility. NLC composition consists of lipid (liquid or solid) and emulsifier (polysorbates /tween, polyvinyl alcohol, pluronic F68 /poloxamer 188, and sodium deoxycholate) ${ }^{80}$

There are various strategies for producing lipid nanoparticles. Some methods that can be used in the preparation of NLC inducing, high-pressure homogenization, microemulsion, phase inversion, emulsification sonification, solvent emulsification-evaporation, solvent diffusion, solvent injection/ solvent displacement method, membrane contactor. ${ }^{81-89}$ The primary procedures are high-pressure homogenization and microemulsion because more stable than other methods. ${ }^{90}$

Rutin, as one of the secondary metabolites, was also know used lipid carrier encapsulation. According to a recent study, the rutin encapsulated lipid carrier has the highest radical inhibition activity for all digestive phases, the highest singlet oxygen scavenging activity after the gastric phase, and the highest antiinflammatory activity for the dialyzable fraction. ${ }^{15}$

\section{Liposome}

Liposomes are phospholipid vesicles that include distinct aqueous gaps and comprise one or more concentric lipid bilayers. Liposomal systems have the unusual capacity to entrap both lipophilic and hydrophilic molecules, allowing them to encapsulate a broad spectrum of medicines. ${ }^{91-94}$ This encapsulation has challenges such as reticuloendothelial system (RES) and liposome clearance, enhanced permeability and retention (EPR) effect, opsonins and vesicle destabilization, accelerated blood clearance (ABC) phenomenon, and complement activation-related pseudoallergy (CARPA). ${ }^{95}$

On the other hand, liposomes have several benefits, including enhanced pharmacological effectiveness and therapeutic index, more excellent stability, and less exposure of sensitive tissue to hazardous medicines. ${ }^{96}$ The stability and antioxidant tests indicated that integrated flavonoids and liposomes had a mutually protective interaction. ${ }^{97}$ Quercetin-loaded liposomes were more stable and had better antioxidant activity than kaempferolloaded liposomes. ${ }^{16}$

\section{Polysaccharide-based enteric-coated nanoparticle}

Polymers based on polysaccharides are usually considered safe and authorized for use as a direct food additive. Different enzymatic susceptibilities of polysaccharides coatings allow for the selective breakdown in the small and large intestines. It was discovered that the polysaccharide covering effectively delayed the encapsulated agent's nonspecific release until it was exposed to its targeted release environment. As a result, this encapsulation may be directed to various organs in the gastrointestinal system and increased oral bioavailability. ${ }^{98}$ The glucose-lowering impact of the P4encapsulated delivery method was found to persist even in the absence of therapy in recent research. The P4-encapsulated delivery method's long-lasting impact might be due to its benefits as a food-grade delivery encapsulation for small-intestinetargeted distribution. ${ }^{17}$

\section{CONCLUSION}

It is known that various secondary metabolites found in Persea americana seeds have an influence on reducing blood glucose levels, notably in the $\alpha$-amylase pathway, based on the results of literature studies. Several forms of potential encapsulation can improve the low bioavailability of secondary metabolites in the body. Herbal substances as adjuvant therapy in T2DM might be a viable management option. However, more study is required to further investigate and understand those effects.

\section{ACKNOWLEDGMENTS}

We are thankful to our supervisor for providing guidance and feedback throughout this literature.

\section{CONFLICT OF INTEREST}

The authors declare there were no conflicts of interest regarding this study.

\section{ETHICS CONSIDERATION}

Ethics approval and informed consent were not required in our study.

\section{FUNDING}

None.

\section{AUTHORS CONTRIBUTION}

All authors are contributed equally to the making of this literature. The first author contributes to the conceptual framework and writes this literature. The second author contributes to ensuring the data sources, analyzing data, and writes this literature. The third author contributes to literature searching, literature collection, and writing the literature. The fourth and fifth author contributes in writing this literature, editing, and formatting the manuscript. The sixth author contributes to supervision. 


\section{REFERENCES}

1. American Diabetes Association. Diagnosis and classification of diabetes mellitus. Vol. 37, Diabetes Care. 2014. 81-90 p.

2. Kemenkes RI. Hari diabetes sedunia tahun 2018. Pusat Data dan Informasi Kementrian Kesehatan RI. 2019. 1-8 p.

3. Megaputri S. Manfaat tanaman mangrove terhadap pengobatan diabetes. J Med Hutama. 2021;2(2):439-47.

4. Oboh G, Ogunsuyi OB, Adegbola DO, Ademiluyi AO, Oladun FL. Influence of gallic and tannic acid on therapeutic properties of acarbose in vitro and in vivo in Drosophila melanogaster. Biomed J. 2019;42(5):317-27.

5. Patala R, Dewi NP, Pasaribu MH. Effectiveness of ethanol extract of avocado seeds (Persea americana Mill.) on blood glucose levels of male white rat (Rattus novergicus) hipercolesterolemia-diabetes model. Galen J Pharm. 2020;6(1):7-13.

6. Badan Pusat Statistik. Statistics of annual fruit and vegetable plants indonesia. Badan Pusat Statistik Indonesia; 2018. 1-99 p.

7. Hayati LN, Tyasningsih W, Praja RN, Chusniati $S$, Yunita MN, Wibawati PA. Isolasi dan identifikasi Staphylococcus aureus pada susu kambing peranakan etawah penderita mastitis subklinis di kelurahan kalipuro, banyuwangi. Med Vet. 2019;2(2):76-82.

8. Kusbiantoro D, Y P. Utilization of secondary metabolite in the turmeric plant to increase community income. J Kultiv. 2018;17(1):544-9.

9. Putri EPK, Hamzah B, Rahman N. Qualitative analysis of bioactive substance in avocado (Persea Americana Mill.) leaf extract and preclinical testing in lowering blood glucose level in mice (Mus musculus). J Akad Kim. 2013;2(3):119-27.

10. Lou W, Chen Y, Ma H, Liang G, Liu B. Antioxidant and $\alpha$-amylase inhibitory activities of tannic acid. J Food Sci Technol [Internet]. 2018;55(9):3640-6. Available from: https://doi. org/10.1007/s13197-018-3292-x [Accessed 25 ${ }^{\text {th }}$ July 2021]

11. Aswathanarayan JB, Vittal RR. Nanoemulsions and their potential applications in food industry. Front Sustain Food Syst. 2019 Nov;3:95.

12. Indratmoko $\mathrm{S}$, Suratmi, Issusilaningtyas $\mathrm{E}$. Formulasi, karakterisasi dan evaluasi self-nano emulsifying drug delivery system (SNEDDS) ekstrak etanol kulit buah nanas sebagai antibakteri streptococcus mutans. Fitofarmaka J Ilm Farm. 2021;11(1):12-22.

13. Mukhopadhyay P, Maity S, Mandal S, Chakraborti AS, Prajapati AK, Kundu PP. Preparation, characterization and in vivo evaluation of $\mathrm{pH}$ sensitive, safe quercetinsuccinylated chitosan-alginate core-shellcorona nanoparticle for diabetes treatment. Carbohydr Polym. 2018 Feb;182:42-51.

14. Chitkara D, Nikalaje SK, Mittal A, Chand M, Kumar N. Development of quercetin nanoformulation and in vivo evaluation using streptozotocin induced diabetic rat model. Drug Deliv Transl Res. 2012 Apr;2(2):112-23.

15. Mel MMRD, Gunathilake KDPP, Fernando CAN. Formulation of microencapsulated rutin and evaluation of bioactivity and stability upon in vitro digestive and dialysis conditions. Int J Biol Macromol. 2020;159:316-23.

16. Huang M, Su E, Zheng F, Tan C. Encapsulation of flavonoids in liposomal delivery systems: the case of quercetin, kaempferol and luteolin. Food Funct. 2017;8(9):3198-208.

17. Sampathkumar K, Riyajan S, Tan CK, Demokritou P, Chudapongse N, Loo SCJ. Small intestine specific delivery of antidiabetic extracts from withania coagulans using polysaccharide based enteric cated nanoparticles. ACS Omega. 2019;4(7):12049-57.

18. Saini V. Molecular mechanisms of insulin resistance in type 2 diabetes mellitus. World J Diabetes. 2010;1(3):68.

19. Cerf ME. Beta cell dysfunction and insulin resistance. Front Endocrinol (Lausanne). 2013;4:1-23.

20. Zheng Y, Ley SH, Hu FB. Global aetiology and epidemiology of type 2 diabetes mellitus and its complications. Nat Rev Endocrinol. 2018;14(2):88-98.

21. Pan X, Meriin A, Huang G, Kandror K V. Insulinresponsive amino peptidase follows the Glut4 pathway but is dispensable for the formation and translocation of insulin-responsive vesicles. Mol Biol Cell. 2019 Jun;30(12):1536-43.

22. Tjandrawinata RR. Patogenesis diabetes tipe 2 : resistensi defisiensi insulin. Dexa Medica Gr. 2016;1-4.

23. Czech MP. Insulin action and resistance in obesity and type 2 diabetes. Nat Med. 2017 Jul;23(7):804-14.

24. Gülçin I, Huyut Z, Elmastaş M, Aboul-Enein HY. Radical scavenging and antioxidant activity of tannic acid. Arab J Chem. 2010;3(1):43-53.

25. Yamashita $Y$, Wang L, Nanba F, Ito C, Toda T, Ashida H. Procyanidin promotes translocation of glucose transporter 4 in muscle of mice through activation of insulin and AMPK signaling pathways. PLoS One. 2016;11(9):119.

26. Alam MM, Meerza D, Naseem I. Protective effect of quercetin on hyperglycemia, oxidative stress and DNA damage in alloxan induced type 2 diabetic mice. Life Sci. 2014;109(1):8-14.

27. Haddad P, Eid $\mathrm{H}$. The antidiabetic potential of quercetin: underlying mechanisms. Curr Med Chem. 2016 Sep;24(4):355-64.

28. Youl E, Bardy G, Magous R, Cros G, Sejalon F, Virsolvy A, et al. Quercetin potentiates insulin secretion and protects INS-1 pancreatic-cells against oxidative damage via the ERK1/2 pathway. Br J Pharmacol. 2010;161(4):799-814.

29. Kappel VD, Cazarolli LH, Pereira DF, Postal BG, Zamoner A, Reginatto FH, et al. Involvement of GLUT-4 in the stimulatory effect of rutin on glucose uptake in rat soleus muscle. J Pharm Pharmacol. 2013;65(8):1179-86.

30. Cai Y, Fan C, Yan J, Tian N, Ma X. Effects of rutin on the expression of PPAR $\gamma$ in skeletal muscles of $\mathrm{db} / \mathrm{db}$ mice. Planta Med. 2012;78(9):861-5.

31. Sun C, Wang L, Sun J, Wang Z, Tang Z. Hypoglycemic and hypolipidemic effects of rutin on hyperglycemic rats. J Tradit Chinese Med. 2020 Aug;40(4):640-5.

32. Alkhalidy H, Moore W, Wang Y, Luo J, McMillan RP, Zhen W, et al. The flavonoid kaempferol ameliorates streptozotocin-induced diabetes by suppressing hepatic glucose production. Molecules. 2018;23(9).

33. Kwon DY, Kim YS, Ryu SY, Choi YH, Cha MR, Yang HJ, et al. Platyconic acid, a saponin from Platycodi radix, improves glucose homeostasis by enhancing insulin sensitivity in vitro and in vivo. Eur J Nutr. 2012;51(5):529-40.

34. Sathish Kumar D, Vamshi Sharathnath K, Yogeswaran P, Harani A, Sudhakar K, Sudha P, et al. A medicinal potency of Momordica charantia. Int J Pharm Sci Rev Res. 2010;1(2):95-100

35. Putta S, Sastry Yarla N, Kumar Kilari E, Surekha C, Aliev G, Basavaraju Divakara M, et al. Therapeutic potentials of triterpenes in diabetes and its associated complications. Curr Top Med Chem. 2016;16(23):2532-42.

36. Khathi A, Serumula MR, Myburg RB, Van Heerden FR, Musabayane CT. Effects of syzygium aromaticum-derived triterpenes on postprandial blood glucose in streptozotocininduced diabetic rats following carbohydrate challenge. PLoS One. 2013;8(11):1-8.

37. Rasouli H, Yarani R, Pociot F, PopovićDjordjević J. Anti-diabetic potential of plant alkaloids: revisiting current findings and future perspectives. Pharmacol Res [Internet]. 2020;155:104723. Available from: https://doi. org/10.1016/j.phrs.2020.104723 [Accessed 27 ${ }^{\text {th }}$ July 2021]

38. Chueh WH, Lin JY. Berberine, an isoquinoline alkaloid in herbal plants, protects pancreatic islets and serum lipids in nonobese diabetic mice. J Agric Food Chem. 2011;59(14):8021-7.

39. Krzyzowska M, Tomaszewska E, RanoszekSoliwoda K, Bien K, Orlowski P, Celichowski G, et al. Tannic acid modification of metal nanoparticles: possibility for new antiviral applications. Vol. 1, Nanostructures for Oral Medicine. Elsevier Inc; 2017. 335-363 p.

40. Mamta K, Sashi J. Tannins: an antinutrient with positive Eefect to manage diabetes. Res J Recent Sci. 2012;1(12):1-8.

41. Arukwe U, Amadi B, Duru M, Agomuo E, Adindu E, Odika P, et al. Chemical composition of Persea americana leaf, fruit and seed. Int J Res Revies Appl Sci. 2012;11(2):346-9.

42. Setyawan HY, Sukardi S, Puriwangi CA. Phytochemicals properties of avocado seed: a review. IOP Conf Ser Earth Environ Sci. 2021;733(1).

43. Al-Ishaq RK, Abotaleb M, Kubatka P, Kajo $\mathrm{K}$, Büsselberg D. Flavonoids and their antidiabetic effects: cellular mechanisms and effects to improve blood sugar levels. Biomolecules. 2019;9(9).

44. David AVA, Arulmoli R, Parasuraman S. Overviews of biological importance of quercetin: a bioactive flavonoid. Pharmacogn Rev. 2016 Jul;10(20):84.

45. Rosero JC, Cruz S, Osorio C, Hurtado N. Analysis of phenolic composition of byproducts (seeds and peels) of avocado (Persea americana Mill.) cultivated in colombia. Molecules. 2019;24(17).

46. Ghorbani A. Mechanisms of antidiabetic effects of flavonoid rutin. Biomed Pharmacother. 2017;96:305-12. 
47. Amiraragab B, Hussein SA, Alm-Eldeen A-E, Hafe Z A, Mohamed T. Diabetes management saponins and their potential role in diabetes mellitus. Diabetes Manag. 2017;7(1):148-58.

48. Morais FS, Canuto KM, Ribeiro PRV, Silva AB, Pessoa ODL, Freitas CDT, et al. Chemical profiling of secondary metabolites from Himatanthus drasticus (Mart.) plumel latex with inhibitory action against the enzymes $\alpha$-amylase and $\alpha$-glucosidase: in vitro and in silico assays. J Ethnopharmacol. 2020;253:112644.

49. Sales PM, Souza PM, Simeoni LA, Silveira D. a-Amylase inhibitors: a review of raw material and isolated compounds from plant source. J Pharm Pharm Sci. 2012;15(1):141-83.

50. Loizzo MR, Marrelli M, Pugliese A, Conforti F, Nadjafi F, Menichini F, et al. Crocus cancellatus subsp. damascenus stigmas: chemical profile, and inhibition of $\alpha$-amylase, $\alpha$-glucosidase and lipase, key enzymes related to type 2 diabetes and obesity. J Enzyme Inhib Med Chem. 2016;31(2):212-8.

51. Subba B, Gaire S, Raj Sharma K. Analysis of phyto-constituents, antioxidant, and alpha amylase inhibitory activities of Persea Americana Mill., Rhododendron Arboretum Sm. Rubus Ellipticus Sm. from arghakhanchi district nepal. Asian J Pharm Clin Res. 2019;12(1):301.

52. Kato CG, De Almeida Gonçalves G, Peralta RA, Seixas FAV, De Sá-Nakanishi AB, Bracht $\mathrm{L}$, et al. Inhibition of $\alpha$-amylases by condensed and hydrolysable tannins: focus on kinetics and hypoglycemic actions. Enzyme Res. 2017;2017:1-12.

53. Alhassan AJ, Sule MS, El-tảalu AB, Lawal AT. In vitro inhibitory activities of Persea americana seed extracts on $\alpha$-amylase and $\alpha$-glucosidas. Bayero J Pure Appl Sci. 2018;10(1):546.

54. Papoutsis K, Zhang J, Bowyer MC, Brunton N, Gibney ER, Lyng J. Fruit, vegetables, and mushrooms for the preparation of extracts with $\alpha$-amylase and $\alpha$-glucosidase inhibition properties: a review. Food Chem [Internet]. 2021;338:128-119. Available from: https:// doi.org/10.1016/j.foodchem.2020.128119 [Accessed 28 ${ }^{\text {th }}$ July 2021]

55. Gonçalves R, Mateus N, de Freitas V. Inhibition of $a$-amylase activity by condensed tannins. Food Chem. 2011;125(2):665-72.

56. Li K, Yao F, Xue Q, Fan H, Yang L, Li X, et al. Inhibitory effects against $a$-glucosidase and $a$-amylase of the flavonoids-rich extract from Scutellaria baicalensis shoots and interpretation of structure-activity relationship of its eight flavonoids by a refined assign-score method. Chem Cent J. 2018;12(1):1-11.

57. Proença C, Freitas M, Ribeiro D, Tomé SM, Oliveira EFT, Viegas MF, et al. Evaluation of a flavonoids library for inhibition of pancreatic a-amylase towards a structure-activity relationship. J Enzyme Inhib Med Chem. 2019;34(1):577-88.

58. Aisyah LS, Ilfani D, Lestari FP, Yun YF. a-amylase inhibition activities by flavonoid compounds from panda plants (Kalanchoe tomentosa). J Kim Sains dan Apl. 2020;23(3):96-101.

59. AK MD, Juliani, Sugito, Abrar M. $\alpha$-amylase and a-glucosidase inhibitors from plant extracts. J Med Vet. 2019;13(2):151-8.
60. Luliana S, Desnita R, Martien R, Nurrochmad A. Total flavonoid contents and in silico study of flavonoid compounds from Meniran (Phyllanthus niruri L.) towards alpha-amylase and alpha-glucosidase enzyme. Pharmaciana. 2019;9(1):1-10.

61. Nafiu MO, Ashafa AOT. Antioxidant and inhibitory effects of saponin extracts from dianthus basuticus burtt davy on key enzymes implicated in type 2 diabetes in vitro. Pharmacogn Mag [Internet]. 2017;13(52):57682. Available from: https://pubmed.ncbi.nlm. nih.gov/29200716 [Accessed $28^{\text {th }}$ July 2021]

62. Nazaruk J, Borzym-Kluczyk M. The role of triterpenes in the management of diabetes mellitus and its complications. Phytochem Rev [Internet]. 2015;14(4):675-90. Available from: http://dx.doi.org/10.1007/s11101-014-9369-x [Accessed 28 ${ }^{\text {th }}$ July 2021]

63. Dandekar PD, Kotmale AS, Chavan SR, Kadlag PP, Sawant S V., Dhavale DD, et al. Insights into the inhibition mechanism of human pancreatic $\alpha$-amylase, a type 2 diabetes target, by dehydrodieugenol $\mathrm{b}$ isolated from ocimum tenuiflorum. ACS Omega. 2021;6(3):1780-6.

64. Bravo-alfaro DA, Muñoz-correa MOF, Santosluna D, Toro- JF, Cano-sarmiento C, Garcíavarela $\mathrm{R}$, et al. Encapsulation of an insulinmodified phosphatidylcholine complex in a self-nanoemulsifying drug delivery system (SNEDDS) for oral insulin delivery. J Drug Deliv Sci Technol. 2020;1-32.

65. Huda N, Wahyuningsih I. Karakterisasi self-nanoemulsifying drug delivery system (SNEDDS) minyak buah merah (Pandanus cnoideus Lam.). J Farm dan Ilmu Kefarmasian Indones. 2016;3(2):49-57.

66. Mohammed MA, Syeda JTM, Wasan KM, Wasan EK. An overview of chitosan nanoparticles and its application in non-parenteral drug delivery. Pharmaceutics. 2017;9(53):1-26.

67. Lertsutthiwong $P, \quad$ Noomun $K$, Jongaroonngamsang N, Rojsitthisak P, Nimmannit U. Preparation of alginate nanocapsules containing turmeric oil. Carbohydr Polym. 2008 Oct;74(2):209-14.

68. Setty CM, Sahoo SS, Sa B. Alginate-coated alginate-polyethyleneimine beads for prolonged release of furosemide in simulated intestinal fluid. Drug Dev Ind Pharm. 2005;31(4-5):43546.

69. Thai H, Thuy Nguyen C, Thi Thach L, Thi Tran M, Duc Mai H, Thi Thu Nguyen T, et al. Characterization of chitosan/alginate/ lovastatin nanoparticles and investigation of their toxic effects in vitro and in vivo. Sci Rep. 2020;10(1):1-15.

70. Mujtaba MA, Alotaibi NM. Chitosansodium alginate nanoparticle as a promising approach for oral delivery of rosuvastatin calcium: formulation, optimization and in vitro characterization. J Pharm Res Int. 2020;32(1):50-6.

71. Lertsutthiwong P, Rojsitthisak P, Nimmannit U. Preparation of turmeric oil-loaded chitosanalginate biopolymeric nanocapsules. Mater Sci Eng C. 2009 Apr;29(3):856-60.

72. Acharya S, Sahoo SK. PLGA nanoparticles containing various anticancer agents and tumour delivery by EPR effect. Adv Drug Deliv Rev. 2011 Mar;63(3):170-83.

73. Danhier F, Ansorena E, Silva JM, Coco R, Le Breton A, Préat V. PLGA-based nanoparticles: an overview of biomedical applications. J Control Release. 2012 Jul;161(2):505-22.

74. Cun D, Jensen DK, Maltesen MJ, Bunker M, Whiteside P, Scurr D, et al. High loading efficiency and sustained release of siRNA encapsulated in PLGA nanoparticles: quality by design optimization and characterization. Eur J Pharm Biopharm. 2011 Jan;77(1):26-35.

75. Sharma S, Parmar A, Kori S, Sandhir R. PLGA-based nanoparticles: a new paradigm in biomedical applications. TrAC - Trends Anal Chem. 2016 Jun;80:30-40.

76. Ding D, Zhu Q. Recent advances of PLGA micro/nanoparticles for the delivery of biomacromolecular therapeutics. Mater Sci Eng C. 2018 Nov;92:1041-60.

77. Rezvantalab S, Drude NI, Moraveji MK, Güvener N, Koons EK, Shi Y, et al. PLGAbased nanoparticles in cancer treatment. Front Pharmacol. 2018 Nov;9:1-19.

78. Silva ATCR, Cardoso BCO, Silva MESRe, Freitas RFS, Sousa RG. Synthesis, characterization, and study of PLGA copolymer in vitro degradation. J Biomater Nanobiotechnol. 2015 Jan;6(1):8-19.

79. Babazadeh A, Ghanbarzadeh B, Hamishehkar H. Novel nanostructured lipid carriers as a promising food grade delivery system for rutin. J Funct Foods. 2016 Oct;26:167-75.

80. Nobari Azar FA, Pezeshki A, Ghanbarzadeh B, Hamishehkar H, Mohammadi M. Nanostructured lipid carriers: promising delivery systems for encapsulation of food ingredients. J Agric Food Res. 2020 Dec;2:1-8.

81. Štecová J, Mehnert W, Blaschke T, Kleuser B, Sivaramakrishnan R, Zouboulis CC, et al. Cyproterone acetate loading to lipid nanoparticles for topical acne treatment: particle characterisation and skin uptake. Pharm Res. 2007 Mar;24(5):991-1000.

82. Huang Z, Hua S, Yang Y, Fang J. Development and evaluation of lipid nanoparticles for camptothecin delivery: a comparison of solid lipid nanoparticles, nanostructured lipid carriers, and lipid emulsion. Acta Pharmacol Sin. 2008 Sep;29(9):1094-102.

83. Ruktanonchai U, Bejrapha P, Sakulkhu $\mathrm{U}$, Opanasopit P, Bunyapraphatsara N, Junyaprasert V, et al. Physicochemical characteristics, cytotoxicity, and antioxidant activity of three lipid nanoparticulate formulations of alpha-lipoic acid. AAPS PharmSciTech. 2009;10(1):227-34.

84. Doktorovová S, Araújo J, Garcia M, Rakovsky E, Souto EB. Formulating fluticasone propionate in novel PEG-containing nanostructured lipid carriers (PEG-NLC). Colloids Surf B Biointerfaces. 2010;75(2):538-42.

85. Souza LG, Silva EJ, Martins ALL, Mota MF, Braga RC, Lima EM, et al. Development of topotecan loaded lipid nanoparticles for chemical stabilization and prolonged release. Eur J Pharm Biopharm. 2011;79(1):189-96.

86. Souto EB, Almeida AJ, Müller RH. Lipid nanoparticles $\left(\mathrm{SLN}^{\star}, \mathrm{NLC}^{\circledR}\right)$ for cutaneous drug 
delivery: structure, protection and skin effects. J Biomed Nanotechnol. 2007 Dec;3(4):317-31.

87. Das $\mathrm{S}$, Chaudhury A. Recent advances in lipid nanoparticle formulations with solid matrix for oral drug delivery. AAPS PharmSciTech. 2011 Dec;12(1):62-76.

88. Amasya G, Badilli U, Aksu B, Tarimci N. Quality by design case study 1: design of 5-fluorouracil loaded lipid nanoparticles by the w/o/w double emulsion-solvent evaporation method. Eur J Pharm Sci. 2016;84:92-102.

89. Schubert M, Müller-Goymann C. Solvent injection as a new approach for manufacturing lipid nanoparticles-evaluation of the method and process parameters. Eur J Pharm Biopharm. 2003;55(1):125-31.

90. Charcosset C, El-Harati A, Fessi H. Preparation of solid lipid nanoparticles using a membrane contactor. J Control Release. 2005;108(1):11220.
91. Koning GA, Storm G. Targeted drug delivery systems for the intracellular delivery of macromolecular drugs. Drug Discov Today. 2003 Jun;8(11):482-3.

92. Metselaar JM, Storm G. Liposomes in the treatment of inflammatory disorders. Expert Opin Drug Deliv. 2005 May;2(3):465-76.

93. Hua S, Wu SY. The use of lipid-based nanocarriers for targeted pain therapies. Front Pharmacol. 2013;4:1-7.

94. Ding B, Dziubla T, Shuvaev V, Muro S, Muzykantov VR. Advanced drug delivery systems that target the vascular endothelium. Mol Interv. 2006 Apr;6(2):98-112.

95. Sercombe L, Veerati T, Moheimani F, Wu SY, Sood AK, Hua S. Advances and challenges of liposome assisted drug delivery. Front Pharmacol. 2015;6:1-13.
96. Choudhury A, Sonowal K, Laskar RE, Deka D, Dey BK. Liposome: a carrier for effective drug delivery. J Appl Pharm Res. 2020;8(1):22-8.

97. Arsana I, Adiputra N, Pangkahila J, PutraManuaba I. 2014. Garcinia mangostana L. rind extract and physical training reduce oxidative stress in wistar rats during maximal physical activity. Indonesia Journal of Biomedical Science 7(2): 63-68. DOI:10.15562/ijbs.v7i2.117

98. Sampathkumar K, Loo SCJ. Targeted gastrointestinal delivery of nutraceuticals with polysaccharide-based coatings. Macromol Biosci. 2018 Apr;18(4):1-11.

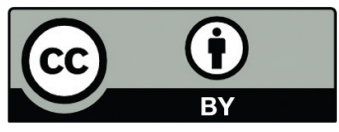

This work is licensed under a Creative Commons Attribution 